\title{
Types and quantities of weeds found in corn fields and the effect of herbicides on grain yield
}

\author{
Nilufar Turdiyeva ${ }^{1, *}$, Zulaykho Umarova ${ }^{1}$, Nazokat Sayfullaeva ${ }^{2}$, Dilnura Togaeva ${ }^{1}$, and \\ Shakrizoda Bahodirova ${ }^{1}$ \\ ${ }^{1}$ Tashkent State Agrarian University, University str., 2, Tashkent province, 100140 Uzbekistan \\ ${ }^{2}$ Namangan Institute of Engineering and Technology, Kasansay str., 7, Namangan, 160115 \\ Uzbekistan
}

\begin{abstract}
Agrotechnical measures and crop rotation also do not ensure complete eradication of weeds. Therefore, it is necessary to use herbicides. Mapping by type and quantity of weeds grown among agricultural crops should be carried out in all crop rotation fields and herbicides should be applied on this basis, i.e. it is important to choose one or another herbicide based on the study of the composition and amount of weeds grown in fields. In the cultivation of corn in Uzbekistan, first of all, it should be aimed at obtaining high yields from its grain. To do this, it is necessary to use all available agro-technical measures. In modern intensive farming, weed control, which is common among agricultural crops, is a key measure.
\end{abstract}

\section{Introduction}

Corn is one of the most widely grown and distributed cereals in the world. It is a fodder, food and technical crop. For food, $20 \%$ of the world's corn is used for technical purposes, $15-20 \%$, and the remaining two-thirds is used for fodder $[1,5,9]$.

Grain contains $65-70 \%$ of carbohydrates, $9-12 \%$ of protein, $4-8 \%$ of fat, as well as mineral salts and vitamins. Its grains include flour, cereals, canned food (sugar corn), ethyl alcohol, dextrin, beer, glucose, sugar, jam, wine, honey, oil, vitamin E, ascorbic and glutamic acids, corn sticks, milk and many other products are made. Maternal threads of corn are used in medicine in diseases of the gallbladder, liver [2, 3, 7]. Paper, linoleum, viscose, activated charcoal, artificial foam, plastic, analgesics, etc. are extracted from the stems, leaves and stalks. Corn kernels, green mass, silage and soybeans, as well as it is an excellent food. $1 \mathrm{~kg}$ of grain contains 1.34 nutrients and $78 \mathrm{~g}$ of digestible protein. Corn is a valuable component in the preparation of mixed fodder. The main protein in its grain, zein, is low in the essential amino acids tryptophan and lysine $[1,3]$.

$100 \mathrm{~kg}$ of silage mass harvested during the milk-wax ripening phase contains 21 nutrient units and $1800 \mathrm{~g}$ of digestible protein [4]. It stores 37 nutrients in its dry stems and leaves and 35 nutrients in its stem. Due to the fact that the row spacing is a cultivated crop, it is a good predecessor for many crops, including fall cereals, cotton and vegetable crops.

\footnotetext{
*Corresponding author: nilturdieva@yandex.com
} 
Therefore, the development of technologies for growing corn in our country, including the control of weeds, is of great importance $[6,8]$. Because weeds are strong competitors to plants, they absorb nutrients, water and light from the soil. Causes the spread of various diseases and pests [9].

The germination capacity of weed seeds is very high and it is precisely the soil that is adapted to the climatic conditions of the region. When not controlled, corn yields and grain quality decline. The reasons for the spread of weeds are varied, mainly through the use of non-rotting organic fertilizers and the fact that weed seeds on the waterfront enter through water when they are not lost before ripening $[4,7,8]$. Therefore, high-quality yields will not be possible without the use of weed control between the fields, along with the cleaning of the fields and waterfronts before the weed seeds ripen. This is because manual weeding of corn fields requires hard work and high costs. It also absorbs $\mathrm{SO}_{2}$ using weed leaves. The culture overshadows the plants and has a negative effect on the process of photosynthesis, and the transpiration coefficient increases, resulting in a sharp increase in the demand of plants for water. With this in mind, the development and implementation of a chemical method of weed control in corn fields is one of the urgent tasks of today $[2,5]$.

The increase in grain production in Uzbekistan should first of all be ensured by increasing yields. For this it is necessary to use all available reserves. In the conditions of modern intensive farming, weed control is one of the most important elements of the farming system, on which the increase in crop yields depends [10,11]. Corn is perhaps the most valuable crop grown for animal feed, as well as for grain. However, growing corn is not as easy as it might seem to a beginner, as corn yield is affected by the level of weed infestation. The productivity of weeds in seed production depends not only on the conditions in which they grow, but also on the period in which they germinate. Early germination of weeds produces more seeds. Weeds that germinate later and develop significantly with the help of herbicides produce relatively few seeds. One of the main characteristics of weed seeds is that they germinate at different times of the year. That is why it is impossible to lose them completely $[11,12]$.

Agrotechnical measures and crop rotation also do not ensure complete eradication of weeds $[13,14]$. Therefore, it is necessary to use herbicides. Mapping by type and quantity of weeds grown among agricultural crops should be carried out in all crop rotation fields and herbicides should be applied on this basis, ie it is important to choose one or another herbicide based on the study of the composition and amount of weeds grown in fields.

In the normally plowed variant, it is grown in areas subject to wind erosion at a depth of 20-22, in the variant at a depth of 40-42 cm, 23-24, and in soils with different depths over the years, $28-30 \mathrm{q} / \mathrm{ha}$. So, to reduce the number of perennial and partial weeds, the following should be done: the field covered with super weeds is first loosened to a thickness of 20-22 cm, then chiseled longitudinally and transversely, and stormed in the same way [15]. Weeds collected in the storm are brought to the edge of the ground and burned.

\section{Weeds in cornyards}

Weeds are plants that people do not plant, but grow between crops and cause damage to them, making it inappropriate to grow in a certain area. They reduce the yield of cultivated plants and will cause great damage. Globally, weed loss due to weeds is estimated at 20 billion tons or $14.5 \%$ of the total harvest, cotton in Uzbekistan, etc. $15-20 \%$ of crop yields [15]. Weeds have a strong developed root system and use more nutrients and moisture in the soil than cultivated plants, which hinders their development and high yields. A welldeveloped bush can occupy an area of $3-4 \mathrm{~m}^{2}$ in loamy soil. The parasite weeds (lizard, 
sorrel) are extremely dangerous, asking for nutrients directly from the cultivated plant it and destroying them $[1,6]$.

Annual weeds bear fruit and seeds only once in their life and their development last only one or two growing seasons. Their roots develop only in the surface layers of the earth. Most are propagated by seeds (except squirrels). This group includes 3 types of weeds. Ephemerals are annual weeds that end their life with the onset of a summer drought and have a fast and short growth cycle. These are available in autumn and spring forms. Ephemerals are mainly distributed in rainfed crops $[4,5]$.

Unlike ephemeral annual weeds, which have a long growth cycle, the development cycle lasts longer and usually ends in the fall. The development of some species (spring forms) begins in early spring, with the warming of the days (e.g., squirrel, ostrich, etc.) But most species belong to the autumn form. Biennial weeds overwinter, forming a ball in the first year of life. In the second year, the stem develops, the fruit is exhausted and dies (eg, goosefoot) - a lot of effort and money is spent to get rid of them. Perennial weeds bloom and fertilize several times in their lives. They can also reproduce with underground organs. Depending on the structure and appearance of the underground organs, perennial weeds can be divided into several types. It has a main root with arrows and many small roots and root hairs that come out of it. These plants do not reproduce in the vegetative way b-n [1-7].

In order to control weeds in maize fields, it is first necessary to identify and prevent the causes of their spread. Along with cultivated crops, weed seeds are also ripened, most of which is sown in the ground, and some of which is mixed with the seed grain. Therefore, the purity of the seed is important [5].

The cleaning of weeds around the ditches before the seeds ripen reduces their infiltration through the waterway. In addition, well-rotted manure is a source of weed seeds. Therefore, it is not recommended to use rotten manure to feed around fields and crop fields. If necessary, it is advisable to use a well-rotted or composted. In addition, the introduction of crop rotation and chronic sowing of the same crops, the lack of timely and quality agrotechnical measures are among them. Weed proliferation is also observed when corn is planted too sparsely [4-9].

The spread of weeds is prevented by the application of internal and external quarantine measures. Among the seeds imported from abroad, it is expected that the most dangerous weeds will enter and pass from one region to another. For example, several types of ivy, require the observance of internal quarantine rules. There are several ways to control weeds. To do this, agro-technical measures will be taken, as well as measures to prevent the spread, as described above. Examples of such activities are tillage and plowing.

To reduce the amount of weeds, crop areas are plowed at the required level with twotiered plows in the fall [11-14]. Weed seeds should be buried to a depth of 32-36 cm. To do this, the use of tweezers is effective. It is necessary to remove the roots by scratching perennial weeds (spruce, gum), which are propagated by some root buds. In addition, the results of plowing at different depths each year are also good. For example 25, 30, 40 and so on. In this case, the layer of weed seeds does not rise to the surface. Proper setting of planting dates and norms, mulching, and the use of crop rotation also lead to a reduction in the number of weeds.

In addition, a chemical method of weed control can be used. As well as the beneficial aspects of this method, the harmful properties must also be taken into account. This type of weed control pesticide is called a herbicide. Herbicides are toxic substances with different levels and also have a negative effect on cultivated plants, soil, flora and fauna. Therefore, extreme caution is required when using herbicides $[10,14]$.

The dosage of exposure to herbicides varies. These include mass influences and selective influences. Mass-effect herbicides should be applied where crops are not planted, 
after crops have been harvested, and at field edges. Because the toxicity of these herbicides is very high, ie first-rate, there is a high probability that the cultivated plants will dry out even shrubs and trees. It also releases toxins into the air and slowly pollutes the soil, leaving its own residue in the soil. Poison from the soil infects humans and animals through the respiratory tract $[4,7,9]$.

The next is selective herbicides. This type of herbicide has a slightly lower toxicity level (3 degrees) and can be used on crops during the growing season. These herbicides are absorbed into the leaves and stems of weeds and act on the enzyme lactacintetase enzyme in the plant. It stops the work of these enzymes that allow cells to divide and multiply. Herbicides are more effective when the soil moisture is sufficient. There should be enough moisture in the soil to enhance the effect of herbicides. Two or three hours after the application of herbicides, the weeds stop growing. It becomes apparent in fifteen days and the effect can be maintained for up to 60 days [1-3].

Another important indicator must be taken into account when using herbicides. This is the air temperature. When the air temperature is too low or high, the level of exposure to herbicides drops sharply. When using herbicides against weeds, it is advisable that the air temperature is below $20-24^{\circ} \mathrm{C}$, soil moisture is below 55-65 degrees or higher, and the wind speed is not higher than $2-3 \mathrm{~m} / \mathrm{sec}[2,9]$.

\section{Classification of the most common weeds in the experiment}

Goosefoot - Ch. album L - an annual weed. Stems erect or spreading over the ground, 30$80 \mathrm{~cm}$ tall. The leaves are banded, the lower leaves are oval-rhombic, the upper ones are oblong-lanceolate. The fruit is a flat round sac. Inflorescence short, without leaves. A single plant will have about 10,000-150,000 seeds. It does not lose its forgetfulness for up to 10 years. The temperature of $5-7{ }^{\circ} \mathrm{C}$ and the optimum temperature of $17-24{ }^{0} \mathrm{C}$ are sufficient for germination of seeds and they bloom and fertilize from May to July.

Quinoa - A. flabelium Bunge - an annual weed. Stems are erect, height is $15-80 \mathrm{~cm}$. The leaves are arranged in series, banded, with a spear-shaped tip, with serrated teeth. The surface of the leaves is hairless, glossy, dark green, sometimes slightly grayish-dusty, and blooms and fertilizes from May to July, and grows among crops.

Buckwheat - F. esculentum Moench. - an annual weed. Stems solitary, smooth, 30-80 $\mathrm{cm}$ in height, 2-4 mm thick, usually located in the axils of leaves on short horns. The leaves are heart-shaped, round, or lower-leaved, pointed, hairless, and bloom in May, as well as growing between irrigated crops.

Coleseed - B. campestris L. - an annual weed. Stems are erect, 20-100 cm tall. The lower leaves are trimmed liranamo-patsimon. Seeds are reddish-brown, sarmoy. The beak is $3-8 \mathrm{~cm}$ long with a beak. One bush plant has 20,000 seeds. The lowest temperature of 3-4 ${ }^{0} \mathrm{C}$ is sufficient for seed germination. The seeds germinate at a depth of $4-5 \mathrm{~cm}$ and bloom and fertilize in April and June, as well as grow between vegetable and melon crops. Occurs in all regions of Uzbekistan.

Shepherd's purse - C. bursa-astoris (L.) MedIk. - an annual weed. Stems simple or branched, hairless, or covered with feathers, height $10-50 \mathrm{~cm}$. The lower leaves are lanceolate, lanceolate. The leaves on the stem are arranged in a row, without small bangs. The flowers are white buds. One bush plant has about 1,200-73,000 seeds. The lowest temperature of $1-2{ }^{0} \mathrm{C}$ and the optimum temperature of $15-26{ }^{\circ} \mathrm{C}$ are sufficient for seed germination. The seeds can germinate at a depth of $3 \mathrm{~cm}$. It blooms and fertilizes in April and May and grows in gardens and among crops.

Thorn apple - D. stramonium L. - an annual weed. Stems are solitary, thick, branched, $1 \mathrm{~m}$ tall. The leaves are elongated, round, triangular, large, the upper side is pointed. The flower is large, trumpet-shaped, white, solitary. The fruit is green, serrate, large. The seeds 
are black, with grooves. One bush plant has about 45,500 seeds. At a temperature of 10-12 ${ }^{0} \mathrm{C}$ and the optimum temperature $24-28{ }^{\circ} \mathrm{C}$ the seeds begin to germinate and bloom and fertilize in May and September. Grows between irrigated crops and in floodplains and is a common poisonous plant.

Littlewale - L. officinale L. - an annual weed. Stems erect, hairy, branched, $50-80 \mathrm{~cm}$ tall. The leaves are lanceolate. The flowers are dense, glabrous, and the nuts are elongated, ovoid. It blooms and fertilizes in April and May, and grows in vacant lots, along streams, and among crops.

Rechingerlanus dock - R. rechingerIanus A. Los. - a perennial weed. Stems erect, grooved, height $40-200 \mathrm{~cm}$, thickness $5-10 \mathrm{~mm}$. The thickness of the root is $2-3 \mathrm{~cm}$. The leaves are flat, smooth, the edges are wavy veins. The flowers are thick-leaved. The nuts are $2.5 \mathrm{~mm}$ long and $1.5 \mathrm{~mm}$ wide and bloom in May-August, fertilize and grow between crops.

Lappula semiglabra -L. semiglabra (Ldb.) Gurke. - an annual weed. The stem is usually strongly branched at the base, $15-30 \mathrm{~cm}$ in height. The leaves are elongated, linear, or elongated pencil, the lower bands are narrowed. The nuts are smooth, the outside and the disc is convex or smooth, branched along the edges of the disc. Blooms and fertilizes in April-May and grows in gardens and between crops.

Field bindweed -Convolvulus arvensis L. - an annual weed. Common as a weed in fields, orchards, cotton, and cereal crops, and along roadsides. The seeds are small and thorny. Stems slender, creeping, 30-100 cm tall. The flower is large, white-pink. In Uzbekistan, it blooms in May-August and ends in June-October. Propagated vegetatively from seed. A single plant can have up to 600 seeds. The seeds are ovoid, large, triangular, 2.4-4.2 mm long, about $2.6 \mathrm{~mm}$ wide. In adulthood, the arrow root penetrates $2 \mathrm{~m}$ and deeper. From the place where the root is cut, new shoots sprout forth. The squirrel clings to the plants, lays them down, and feeds on the nutrients and moisture in its body. The average weight of one seed is $10.3-16.6 \mathrm{mg}$.

Belvedere - K. scoparia (L) Schrad. - an annual weed. Stems 30-140cm tall, singlestemmed, the stem is branched from the bottom, erect. The leaves are hairless or slightly hairy at the base, three-veined, pencil or pencil - linear, flat. The flowers are located in the axils of leaves 1-3, sometimes 5. Flowering and fertilizing in July-July. One plant contains 10,000 seeds. The seeds germinate at a depth of $5-7 \mathrm{~cm}$. A temperature of $5-7{ }^{0} \mathrm{C}$ is sufficient for seed germination and grows between vacant lots, roadside and irrigated crops.

Tenacious bristle - S.verticillata (L.) Beauv. - an annual weed. Stems erect, hairless, $15-60 \mathrm{~cm}$ tall. The leaves are pencil-shaped, up to $1.5 \mathrm{~cm}$ wide. Ball cylindrical, up to 15 $\mathrm{cm}$ long. The head is covered with $2.5 \mathrm{~mm}$ long lobes. During the season, one plant fertilizes about 50,000. The seeds can germinate at a depth of 16-18 cm. Memory is maintained for up to 30 years. The lowest temperature of $6-8{ }^{0} \mathrm{C}$ and the optimum temperature of $20-24{ }^{\circ} \mathrm{C}$ are sufficient for seed germination and it blooms, fertilizes in JuneSeptember and grows between different crops.

Green foxtail - S. viridis (L.) Beauv. - an annual weed. Stems erect, hairless, 20-70 $\mathrm{cm}$ tall. The leaves are green, pencil-shaped, the upper part is strongly scaly. The edges are sharp. Bundle thick, cylindrical, up to $2 \mathrm{~mm}$ long. The spike is $2.5 \mathrm{~mm}$ long, covered with bristles, the ripe spikes are green, sometimes dark brown. One bush fertilizes up to 2,0003,000 plants. The seeds can germinate at a depth of $12-14 \mathrm{~cm}$. Memory is maintained for up to 4 years. The lowest temperature of $6-8{ }^{\circ} \mathrm{C}$ and the most favorable temperature of $20-24$ ${ }^{0} \mathrm{C}$ are sufficient for seed germination. it blooms and fertilizes in June-September and grows in Bedapoya, among cereals and cotton, and in gardens.

Wild oat - Avena fatua L. - an annual weed. The length of the stem is $80-120 \mathrm{~cm}$. The reserve is more common on the ground. Growing in grain crops causes great damage. It is also found among irrigated crops. The fruit is grainy, flattened, $2.5 \mathrm{~mm}$ long and $2-3 \mathrm{~mm}$ 
wide, 1.5-2.5 mm thick. The leaves are linear, linear, 60-70 $\mathrm{mm}$ long, 4-5 mm wide, with veins running along the edge and middle. Usually there are 2-3 seeds in each spike. Large seeds inside the corn remain in the stalks for a long time when ripe and are significantly contaminated during the harvest of wheat or barley. It blooms and bears fruit in MaySeptember. One bush produces 600 seeds per plant. The dormancy period usually lasts 5-7 months, during which time the germination of seeds reaches $100 \%$. The seeds germinate well at a depth of $10 \mathrm{~cm}$, and germination can be observed for 5-8 years.

Bermuda grass - C. dactylon (L.) Pers. - a perennial weed. The stem is articulated, branched at the bottom, $10-50 \mathrm{~cm}$ tall. It is a slender bluish, pen-ribbon-leafed, claw-like plant with a rhizome, creeping. The fruit is grainy, ovoid, flat-triangular, $3 \mathrm{~mm}$ long, and $1 \mathrm{~mm}$ wide. Mainly propagated by root, and in one season a single plant fertilizes about 1-2 thousand and blooms in June-August. It grows among irrigated crops, in abandoned lands, on roadsides.

Johnson grass - S. halepense (L.) Pers. - a perennial weed. It has a rhizome, the stem is straight, $1-2 \mathrm{~cm}$ thick, $50-150 \mathrm{~cm}$ long, hairless. It is propagated by seeds and rhizomes of the plant. The fruits are grainy, 5-6 mm long, $2 \mathrm{~mm}$ wide and 1.5-1.7 mm thick. One plant can produce up to 2,000-3,000 seeds. The seeds germinate at a depth of 7-8 cm. Memory is maintained for up to 4 years. The lowest temperature of $10-12{ }^{\circ} \mathrm{C}$ and the optimum temperature of $20-35{ }^{0} \mathrm{C}$ are sufficient for seed germination. Fertility is maintained for up to 4 years and blooms in May-July, fertilizes in July-September and grows among cotton, cereals and vegetable crops.

\section{Classification of applied herbicides}

Elyumis, md. LTD. This herbicide is manufactured in Switzerland and registered by Singenta [1,4]. The active substance is $75 \mathrm{~g} / 1$ mesotrion $30 \mathrm{~g} / 1$ nicosulfuron, chemical class triketone sulfonylureas. Damage level 3, oily dispersion, shelf life three years. The herbicide is applied in part during the growing season of perennial, annual cereals and dicotyledonous weeds. It has a complex effect against all weeds in the field and does not require the use of other types of herbicides. No phytotoxic condition was observed in maize. The oil in it increases the strength and duration of exposure (Table 1).

Table 1. Dependence of the rate of application of the herbicide Elyumis on the degree of contamination of the crop area.

\begin{tabular}{|c|c|}
\hline Degree of pollution in the developmental phases & Application norm, $\mathbf{~ / h a}$ \\
\hline $\begin{array}{c}\text { The optimal application time for annual cereal weeds is up } \\
\text { to } 3 \text { leaves }\end{array}$ & 1.2 \\
\hline $\begin{array}{c}\text { For annual grain weeds, the application time is when the } \\
\text { humidity is less than 3 leaves }\end{array}$ & 1.4 \\
\hline $\begin{array}{c}\text { When an annual grain weed produces 3-4 leaves } \\
\text { up to 2 leaves }\end{array}$ & 1.5 \\
\hline $\begin{array}{c}\text { The optimal application time for annual biennial weeds is } \\
\text { For annual dicotyledonous weeds, the application time is } \\
\text { when the humidity is less than 2 leaves }\end{array}$ & 1.3 \\
\hline $\begin{array}{c}\text { When annual biennial weeds produce 3 leaves } \\
10-15 \text { cm above the ground }\end{array}$ & 1.5 \\
\hline $\begin{array}{c}\text { The optimum application time for perennial grain weeds is } \\
\text { For perennial grain weeds, the application time is } 15 \mathrm{~cm} \text { and } \\
\text { higher from the ground when the humidity is less }\end{array}$ & 1.7 \\
\hline $\begin{array}{c}\text { When perennial dicotyledonous weeds produce } 2 \text { pairs of } \\
\text { leaves and broad-leaved weeds up to } 12 \text { cm in diameter at } \\
\text { the time of stem formation }\end{array}$ & 1.6 \\
\hline
\end{tabular}


When perennial dicotyledonous weeds produce 3 pairs of leaves and broad-leaved weeds up to $12 \mathrm{~cm}$ in diameter at the time of stem formation

$1.8-2.0$

Miladar Duo - 1.2 1/ha (ethalon) Ukraine. Miladar Duo is one of the most reliable herbicides with high efficiency, applied during the growing season, with a systemic effect $[2,3,5]$. This herbicide simultaneously affects single and perennial cereals and dicotyledonous weeds that occur among them during the growing season of corn.

Features of the herbicide Miladar Duo: suspension concentrate, active substance Mesotrion $100 \mathrm{~g} / \mathrm{l}$, calistemones + produced sulfonylureas, has a level 3 hazard. Other technological processes can be applied 3-7 days after processing. It is mainly packaged in 5 liter containers.

\section{Scope and application of Miladar Duo (Table 2):}

- effective herbicide with a systemic effect against annual and perennial and dicotyledonous weeds in maize fields;

- has a rapid effect of absorption through the stems and leaves of weeds;

- does not have a toxic effect on subsequent crops during crop rotation;

- low levels of toxicity to the environment;

- has the property of affecting the soil through the mesotryon material.

Table 2. Using norms of Miladar Duo herbicide.

\begin{tabular}{|c|c|c|c|}
\hline Crop & Weeds found in the field & Duration of application & $\begin{array}{c}\text { Standard of } \\
\text { application }\end{array}$ \\
\hline Corn & $\begin{array}{c}\text { Annual biphasic, } \\
\text { Annual grain, } \\
\text { Perennial grain }\end{array}$ & When 3-5 (8) leaves developed & $1.2-1.25$ \\
$1 / \mathrm{ha}$
\end{tabular}

Compatibility with other herbicides: Compatible with pesticides and agrochemicals other than hydroxides. It is advisable to check the compatibility of the herbicides before preparing the working mixture. In this case, it is necessary to check that the sediment does not form foam, does not separate into layers, that one of the herbicides is not completely dissolved. It is not recommended to prepare a mixture in one tank with herbicides from the group of phosphorus organic compounds. The application interval is 7 days.

Mechanism of action: herbicide has a systemic effect. Nicosulfuron in the herbicide stops (blocks) the processes responsible for the biosynthesis of essential amino acids in plants. The mesotrion, on the other hand, blocks the action of plant enzymes involved in the synthesis of caratenoids, which in turn expands the absorption spectrum of chlorophyll. The combination of the above two active ingredients allows the removal of weeds that are resistant to herbicides based on 2.4-D, sulfanilure, triazine and others.

Important procedures for use: The herbicide Miladar Duo is not processed between the lines for 7 days before and after use. The herbicide can also be used when corn is raised to 5 bar and 8 bar. Climate $\left(12-25^{\circ} \mathrm{C}\right)$ and soil and air humidity should be optimal during application. Extremely hot and cold temperatures or extreme humidity sharply reduce the potency of the herbicide, so its use in such conditions is not recommended. There are restrictions on some crops during the intercropping process after the application of this herbicide. Other crops than sugar beets, peas and vegetables can be planted.

Super Stomp, 33\% (Uzbekistan) [1-5]. The active ingredient of the super stomp herbicide is pendimethaline. This herbicide is applied against annual biennial and grain weeds. It can be applied at the same time as planting or until the plants sprout. It is applied at 3.0-6.0 $1 /$ ha. The use of this herbicide is not considered dangerous in crop rotation 
Super stomp is a high-yielding soil herbicide. This geobicide is applied to several agricultural crops, as well as has a high and effective effect in the control of weeds found among corn crops. Among the corn weeds found among maize crops are foxtail, wild millet, blue beet, beet grass, wild oats, sorghum, etc. It is effective in eliminating weeds such as grass, sorrel, olabuta, jag-jag, bangidevona, nettle, fat grass, chamomile, purple, black currant.

This herbicide is absorbed from the soil through the roots of the plant, affects the meristem part and stops the growth of weeds. Grain weeds found in maize fields can be obtained in the 1-1.5 leaf phase or dicotyledonous weeds in the 2 leaf phase. This herbicide protects cultivated plants throughout the growing season.

Super stomp preparation is applied in heavy soil conditions before sprouting corn. In humus-rich soils, when there is a very strong heat, it is advisable to use it in high doses in places with low rainfall, in soils with light soils and low humus content. In the use of this herbicide is also taken into account weed species, the rate of application is increased when there is a large amount of weeds, such as foxtail, dog grape, chamomile.

Before applying the herbicide, the soil is well leveled, large lumps are crushed, and then the effectiveness of the application is much higher. Gaitan can also be used in combination with some soil herbicides. The active substances are acetochlorine, imazamox, imazapir, imazetapir, clomasone, metribuzin, promethrin. It can also be used in combination with fungicides and insecticides when the application periods are appropriate.

According to the results of experiments conducted on the lands of "Doston Uychi" farm, Uychi district, Namangan province of Uzbekistan, the number of annual two-stage weeds under control, ie without herbicide application, was 4.9, the number of perennial two-stage weeds averaged 5.3. The number of annual two-stage weeds in the control variant per $1 \mathrm{~m} 2$ area after 15 days after application of herbicides to corn fields: Ch album $L-5.7$ pieces, $A$. flabelium Bunge - 4.5, F esculentum Moench - 4.1, B campestris L - 5.3, C bursa-astoris 5.2, D stramonium $L$ - 4.6, $R$ Raphanistrum $L$ - 4.4, X spinosum L - 4.2, Lithospermum officinale $L-5.2$, average 4.9 pieces i.e. 3 points, perennial dicotyledonous weeds, i.e. $R$ rechingerIanus - 5.6, Galium aparine L - 4.7, Convolvulus sepium L - 5.7, Artemisia vulgaris $L-4.9$, average 4.9 units, ie 2 points.

15 days after application of the herbicide, the Miladar duo - when applied as a $1.2 \mathrm{l} / \mathrm{ha}$ (standard) to annual bilayer weeds: Ch album $L-87.7 \%$, A flabelium Bunge - $86.6 \%, F$ esculentum Moench - 90, 2\%, B campestris L - 88.6\%, C bursa-astoris - $86.5 \%, D$ stramonium $L-89.1 \%, R$ Raphanistrum $L-86.6 \%$, X spinosum $L-90.2 \%$, Lithospermum officinale $L-88.7 \%$, an average of 4.9 pieces or 3 points, perennial dicotyledonous weeds $R$ rechingerIanus - 89.2\%, Galium aparine L - 87.7\%, Convolvulus sepium L - 87.2\%, Artemisia vulgaris $L$ yielded $88.4 \%$, with an average yield of $89.4 \%$.

15 days after application of the herbicide Elyumis 105 applied to 1 1/ha of annual twostage weeds: Ch album L - 89.4\%, A flabelium Bunge - 88.8\%, F esculentum Moench $90.2 \%, B$ campestris $L-86.7 \%$, C bursa-astoris - 90.2\%, D stramonium $L-86.9 \%, R$ Raphanistrum L - 88.8\%, X spinosum L - 90.2\%, Lithospermum officinale L - 86.7\%, an average of $88.7 \%$, perennial dicotyledonous weeds $R$ rechingerIanus - 87.5\%, Galium aparine L - 89.4\%, Convolvulus sepium L - 89.3\%, Artemisia vulgaris L - 88.4\%, on average yielded $88.4 \%$ of the amount.

15 days after application of the herbicide Elyumis 105 applied to $21 /$ ha of annual biphasic weeds: Ch album L - 90.3\%, A flabelium Bunge - 89.4\%, F esculentum Moench 91.8\%, B campestris $L-90.5 \%$, C bursa-astoris - 91.4\%, D stramonium $L-86.1 \%, R$ Raphanistrum L - 88.7\%, X spinosum L - 91.5\%, Lithospermum officinale L - 90.4\% , an average of $90.0 \%$, perennial dicotyledonous weeds $R$ rechingerIanus $-89.2 \%$, Galium aparine L - 89.4\%, Convolvulus sepium L - 89.3\%, Artemisia vulgaris L - 89.3\%, on 
average yielded $89.3 \%$ of the amount. Elyumis showed a higher effect than all weeds when applied at 2 1/ha (Table 3 ).

Table 3. Effects of herbicides applied after maize germination on single and perennial biphasic weeds.

(Namangan province, Uychi district, “Doston Uychi” farm, 2018-2020)

\begin{tabular}{|c|c|c|c|c|c|c|c|c|}
\hline \multirow{2}{*}{ \# } & \multirow{2}{*}{ Name of weeds } & \multirow{2}{*}{$\begin{array}{c}\text { Control } \\
\text { (without } \\
\text { herbicides), } \\
\mathrm{pcs} / \mathrm{m}^{2}\end{array}$} & \multicolumn{2}{|c|}{$\begin{array}{c}\text { Miladar Duo }-1.2 \\
\text { 1/ha (ethalon) }\end{array}$} & \multicolumn{2}{|c|}{$\begin{array}{c}\text { Elyumis } 105 \\
11 / \mathrm{ha}\end{array}$} & \multicolumn{2}{|c|}{$\begin{array}{c}\text { Elyumis } 105 \\
21 / \mathrm{ha}\end{array}$} \\
\hline & & & $\mathrm{pcs} / \mathrm{m}^{2}$ & $\%$ & $\mathrm{pcs} / \mathrm{m}^{2}$ & $\%$ & $\mathrm{pcs} / \mathrm{m}^{2}$ & $\%$ \\
\hline \multicolumn{9}{|c|}{15 days after herbicide application } \\
\hline 1 & Ch album $L$ & 5.7 & 0.6 & 87.7 & 0.6 & 89.4 & 0.5 & 90.3 \\
\hline 2 & A flabelium Bunge & 4.5 & 0.5 & 86.6 & 0.5 & 88.8 & 0.4 & 89.4 \\
\hline 3 & $\begin{array}{l}\text { F esculentum } \\
\text { Moench }\end{array}$ & 4.1 & 0.4 & 90.2 & 0.5 & 90.2 & 0.4 & 91.8 \\
\hline 4 & $B$ campestris $L$ & 5.3 & 0.4 & 88.6 & 0.5 & 86.7. & 0.4 & 90.5 \\
\hline 5 & Cbursa-astoris & 5.2 & 0.5 & 86.5 & 0.6 & 90.3 & 0.5 & 91.4 \\
\hline 6 & D stramonium L & 4.6 & 0.4 & 89.1 & 0.5 & 86.9 & 0.4 & 89.1 \\
\hline 7 & R Raphanistrum L & 4.4 & 0.5 & 86.6 & 0.4 & 88.8 & 0.4 & 88.7 \\
\hline 8 & $X$ spinosum $L$ & 4.2 & 0.4 & 90.2 & 0.4 & 90.2 & 0.3 & 91.2 \\
\hline 9 & $\begin{array}{l}\text { Lithospermum } \\
\text { officinale L }\end{array}$ & 5.2 & 0.4 & 88.7 & 0.5 & 86.7 & 0.3 & 90.4 \\
\hline & Average: & 4.9 & 0.5 & 88.1 & 0.5 & 88.7 & 0.5 & 90.0 \\
\hline 10 & $R$ rechingerIanus & 5.6 & 0.6 & 89.2 & 0.7 & 87.5 & 0.6 & 89.2 \\
\hline 11 & Galium aparine $L$ & 5.7 & 0.7 & 87.7 & 0.6 & 89.4 & 0.6 & 89.4 \\
\hline 12 & $\begin{array}{l}\text { Convolvulus } \\
\text { sepium } L\end{array}$ & 4.7 & 0.6 & 87.2 & 0.5 & 89.3 & 0.5 & 89.3 \\
\hline 13 & $\begin{array}{l}\text { Artemisia vulgaris } \\
L\end{array}$ & 4.9 & 0.6 & 88.4 & 0.6 & 88.4 & 0.5 & 89.3 \\
\hline & Average: & 4.9 & 0.5 & 88.4 & 0.5 & 88.6 & 0.4 & 89.3 \\
\hline \multicolumn{9}{|c|}{30 days after herbicide application } \\
\hline 1 & Ch album L & 5.1 & 0.7 & 86.2 & 0.5 & 90.1 & 0.6 & 88.2 \\
\hline 2 & $\begin{array}{l}\text { A flabelium } \\
\text { Bunge }\end{array}$ & 4.2 & 0.5 & 88.0 & 0.4 & 90.4 & 0.4 & 90.4 \\
\hline 3 & $\begin{array}{l}\text { F esculentum } \\
\text { Moench }\end{array}$ & 5.8 & 0.6 & 89.6 & 0.7 & 87.9 & 0.7 & 87.9 \\
\hline 4 & B campestris $L$ & 4.6 & 0.5 & 89.1 & 0.6 & 86.9 & 0.5 & 89.1 \\
\hline 5 & Cbursa-astoris & 5.3 & 0.7 & 86.7 & 0.5 & 90.5 & 0.6 & 88.6 \\
\hline 6 & D stramonium $L$ & 4.4 & 0.5 & 88.6 & 0.4 & 90.9 & 0.4 & 90.9 \\
\hline 7 & $\begin{array}{l}\text { R Raphanistrum } \\
L\end{array}$ & 5.7 & 0.6 & 89.4 & 0.7 & 87.7 & 0.6 & 89.4 \\
\hline 8 & $X$ spinosum $L$ & 4.1 & 0.4 & 90.2 & 0.5 & 90.2 & 0.4 & 87.8 \\
\hline \multirow[t]{2}{*}{9} & $\begin{array}{l}\text { Lithospermum } \\
\text { officinale L }\end{array}$ & 4.6 & 0.5 & 89.1 & 0.6 & 86.9 & 0.5 & 89.1 \\
\hline & Average: & 5.0 & 0.5 & 88.2 & 0.5 & 89.2 & 0.5 & 89.5 \\
\hline 10 & $\begin{array}{l}R \\
\text { rechingerIanus }\end{array}$ & 4.4 & 0.4 & 90.9 & 0.5 & 88.6 & 0.4 & 90.9 \\
\hline 11 & $\begin{array}{l}\text { Galium aparine } \\
L\end{array}$ & 5.5 & 0.5 & 90.9 & 0.7 & 87.2 & 0.6 & 89.0 \\
\hline 12 & $\begin{array}{l}\text { Convolvulus } \\
\text { sepium L }\end{array}$ & 5.8 & 0.7 & 87.9 & 0.6 & 89.6 & 0.7 & 87.9 \\
\hline \multirow[t]{2}{*}{13} & $\begin{array}{l}\text { Artemisia } \\
\text { vulgaris } L\end{array}$ & 6.1 & 0.6 & 90.1 & 0.7 & 88.5 & 0.6 & 90.1 \\
\hline & Average: & 5.0 & 0.5 & 88.9 & 0.5 & 88.7 & 0.5 & 89.2 \\
\hline \multicolumn{9}{|c|}{60 days after herbicide application } \\
\hline 1 & Ch album $L$ & 5.2 & 0.6 & 88.4 & 0.7 & 86.5 & 0.5 & 90.3 \\
\hline 2 & $\begin{array}{l}\text { A flabelium } \\
\text { Bunge }\end{array}$ & 4.1 & 0.5 & 87.8 & 0.4 & 90.2 & 0.4 & 90.2 \\
\hline
\end{tabular}




\begin{tabular}{|c|c|c|c|c|c|c|c|c|}
\hline 3 & $\begin{array}{l}\text { F esculentum } \\
\text { Moench }\end{array}$ & 5.6 & 0.7 & 87.5 & 0.6 & 89.2 & 0.6 & 89.2 \\
\hline 4 & $B$ campestris $L$ & 4.3 & 0.6 & 86.0 & 0.5 & 88.3 & 0.4 & 90.6 \\
\hline 5 & C bursa-astoris & 5.4 & 0.5 & 90.7 & 0.6 & 88.8 & 0.7 & 87.0 \\
\hline 6 & D stramonium L & 4.7 & 0.6 & 87.2 & 0.5 & 89.3 & 0.5 & 89.3 \\
\hline 7 & $\begin{array}{l}R \text { Raphanistrum } \\
L\end{array}$ & 6.2 & 0.7 & 88.7 & 0.7 & 88.7 & 0.6 & 90.3 \\
\hline 8 & $X$ spinosum $L$ & 5.0 & 0.7 & 86.0 & 0.6 & 88.0 & 0.5 & 90.0 \\
\hline 9 & $\begin{array}{l}\text { Lithospermum } \\
\text { officinale L }\end{array}$ & 4.5 & 0.5 & 88.8 & 0.5 & 88.8 & 0.6 & 86.6 \\
\hline & Average: & 5.0 & 0.6 & 88.0 & 0.5 & 88.7 & 0.5 & 89.5 \\
\hline 10 & $R$ rechingerIanus & 5.4 & 0.5 & 90.7 & 0.7 & 87.0 & 0.6 & 88.8 \\
\hline 11 & $\begin{array}{l}\text { Galium aparine } \\
L\end{array}$ & 4.3 & 0.6 & 86.0 & 0.4 & 90.6 & 0.5 & 88.3 \\
\hline 12 & $\begin{array}{l}\text { Convolvulus } \\
\text { sepium L }\end{array}$ & 6.2 & 0.7 & 88.7 & 0.6 & 90.3 & 0.6 & 90.3 \\
\hline 13 & $\begin{array}{l}\text { Artemisia } \\
\text { vulgaris } L\end{array}$ & 4.5 & 0.6 & 86.6 & 0.5 & 88.8 & 0.5 & 88.8 \\
\hline & Average: & 5.2 & 0.6 & 87.7 & 0.5 & 88.9 & 0.5 & 88.9 \\
\hline & $\mathrm{HCP}_{05}=$ & - & - & 3.19 & & 1.51 & & 1.36 \\
\hline
\end{tabular}

But overuse of herbicides is not always effective. Because the price of herbicides is expensive, as a result of the increase in cost while producing economic efficiency, there is also a decrease in the amount of conditional net income, and accordingly leaves toxins in the soil. This indicates that the herbicide rate can be increased only when the number of weeds, which gave good results when using the above-mentioned herbicide Elyumis 105 at $21 /$ ha, is sharply increased.

In the control variant, due to the excessive number of weeds, a sharp decrease in yield was observed, ie 30.1 quintals. When using the above herbicides, the active ingredient of which is pendemetaline, the Miladar duo - an additional yield of $65.5 \mathrm{q} / \mathrm{ha}$, ie $35.4 \mathrm{q} / \mathrm{ha}$ at $1.2 \mathrm{l} / \mathrm{ha}$ (standard), Elyumis $1051 \mathrm{l} /$ ha yield $68.5 \mathrm{q} /$ ha ha yielded an additional yield of 38.4 $\mathrm{q} / \mathrm{ha}$, while Elyumis 105 yielded an additional yield of $68.7 \mathrm{q} / \mathrm{ha}$ or $38.6 \mathrm{q} / \mathrm{ha}$. Although the highest yield was when Elyumis 105 was applied to $11 /$ ha, little difference was observed compared to when Elyumis 105 was applied to 2 1/ha (Table 4). Given the costeffectiveness, it is advisable to use the herbicide Elyumis $1051 \mathrm{l} / \mathrm{ha}$. It is recommended to use the herbicide Elyumis 1051 1/ha against annual and perennial dicotyledonous weeds.

Table 4. Effect of Elyumis 105 herbicide on corn yield.

(Namangan province, Uychi district, "Doston Uychi” farm, 2018-2020)

\begin{tabular}{|c|c|c|}
\hline Options & Corn yield, quintals/ha & Additional yield, quintal/ha \\
\hline Control (without herbicide) & 30.1 & - \\
\hline Miladar Duo - 1.2 1/ha (ethalon) & 65.5 & 35.4 \\
\hline Elyumis 105 1 1/ha & 68.5 & 38.4 \\
\hline Elyumis 105 2 1/ha & 68.7 & 38.6 \\
\hline
\end{tabular}

One of the important biological features of weeds is that they have been able to grow and reproduce in a variety of ways (from seed, rootstock, buckwheat, etc.) for many millions of years in order to survive and preserve their offspring. Plants that are not found in natural grasslands, especially in hayfields belonging to the same species, are also called weeds.

The main purpose of the study of "weeds" is to develop specific measures to combat them. But weeds with extremely complex biological properties cannot be easily eradicated. Therefore, various methods have been developed to combat them. One of them and the most important is to follow all agronomic rules. 


\section{Conclusions}

In short, weeds are common on irrigated lands, including medicinal and poisonous ones. They propagate and fertilize depending on their biological properties. The reasons for their spread may be due to rotten manure, water, untreated ditches and ditches, crop rotation and untimely application of agro-technical measures. It has been observed that they have the property of drastically reducing yields and grain quality as a result of their strong absorption of nutrients, water and light from the soil, providing shade and compression to cultivated plants. They are highly perishable compared to cultivated plants, the seeds are stored in the soil for a long time, and the amount of seeds is much higher. This, in turn, indicates the need to develop measures to combat them.

Miladar duo - 1.2 1/ha (standard) and Elyumis 1051 1/ha, and the herbicide can be used in cases where the number of weeds is not excessive. When the number of weeds is large, the application of Elyumis in moderation of $21 /$ ha gives good results. This in turn affected productivity. When Elyumis was applied at 2 1/ha, the yield was $68.7 \mathrm{q} / \mathrm{ha}$, i.e. $38.4 \mathrm{q} / \mathrm{ha}$ more than the control.

\section{References}

1. N. Turdiyeva, N. Sayfullaeva, S. Tursunov, M. Fakhriddin kizi, International Journal of Psychosocial Rehabilitation, 4249-4253 (2020)

2. N. Turdiyeva, S. Tursunov, N. Sayfullaeva, Weed plants of corn and methods of dealing with them, 292-298 (2019)

3. Z. Umarova, Problems of Soil and Environmental Protection, 196-198 (2020)

4. Z. Umarova, International Journal of Psychosocial Rehabilitation, 24(5), 6301-6306 (2020)

5. S. Isaev, I. Begmatov, G. Goziev, S. Khasanov, In IOP Conference Series: Materials Science and Engineering, 883(1), 012080 (2020)

6. N. Teshaev, B. Mamadaliyev, A. Ibragimov, S. Khasanov, InterCarto. InterGIS, 26(3), 324-333 (2020)

7. B. de Saagun, S. Kuprienko, Revista Mesoamericana, 218 (2013)

8. S. Isaev, S. Khasanov, Y. Ashirov, T. Karabaeva, A. Gofirov, In E3S Web of Conferences, 244, 02012 (2021)

9. R. A. Kulmatov, S. A. Adilov, S. Khasanov, In IOP Conference Series: Earth and Environmental Science, 614(1), 012149 (2020)

10. B. Sh. Matyakubov, Z. J. Mamatkulov, R. K. Oymatov, U. N. Komilov, G. E. Eshchanova, InterCarto, InterGIS, 26, 229-239 (2020)

11. Y. Gafforov, R. Phookamsak, H. -B. Jiang, D. N. Wanasinghe, M. Juliev, Botany, 97(12), 671-680 (2019)

12. K. Khakimova, I. Musaev, A. Khamraliev, In E3S Web of Conferences, 227, 02003 (2021)

13. N. Ch. Namozov, D. A. Kodirova, M. I. Usmonova, International journal of scientific \& technology research, 9(03), 5491-5493 (2020)

14. S. Isaev, S. Khasanov, Y. Ashirov, A. Gofirov, T. Karabaeva, In E3S Web of Conferences, 244, 02047 (2021)

15. A. Jumanov, S. Khasanov, A. Tabayev, G. Goziev, U. Uzbekov, E. Malikov, In IOP Conference Series: Earth and Environmental Science, 614(1), 012150 (2020) 